\title{
Análise de pós puncionamento em lajes lisas de concreto armado utilizando os recursos do TQS
}

\section{Resumo}

\author{
Yuri V. Moura (IC), Leandro M. Trautwein (PQ)
}

É cada vez mais comum a utilização do sistema estrutural formado por lajes lisas. Esse sistema de laje consiste em estruturas ligadas diretamente sobre os pilares, não existindo a presença das vigas de apoio. Sendo assim, há maior liberdade na definição de espaços internos, menor desperdício, redução da altura total do edifício e aceleração do processo construtivo, dentre outras vantagens. Entretanto, essa concepção estrutural requer análises de estabilidade mais sofisticadas, já que ocorre o processo de puncionamento nas seções em torno dos pilares, o que acarreta em uma maior possibilidade de ocorrência do colapso progressivo da estrutura. Dessa forma, é necessária uma análise mais detalhada na projeção da estrutura para que - caso ocorra uma ruptura localizada por punção - o colapso progressivo seja prevenido, garantido estabilidade e integridade estrutural. Esta pesquisa busca analisar o comportamento o comportamento pós puncionamento de pavimentos em lajes através da análise estrutural utilizando software TQS.

Palavras Chave: Pós puncionamento, concreto armado, TQS

\section{Introdução}

O sistema estrutural formado por lajes lisas é baseado na ligação direta laje-pilar (excluindo a presença de vigas), o que promove benefícios econômicos e estruturais, tais como aceleração do processo construtivo.

Não obstante, tal procedimento sofre o efeito de puncionamento (concentração de esforços na região de apoio), o qual é capaz de gerar o colapso progressivo da estrutura - propagação de uma ruptura localizada que resulta em uma ruptura desproporcional a inicial - devido a perda total ou parcial da capacidade de apoio de uma ligação laje-pilar.

Por conseguinte, a análise do comportamento estrutural pós puncionamento em lajes lisas é de suma importância para que a segurança e integridade de tal sistema sejam asseguradas.

\section{Resultados e Discussão}

A priori, foram realizadas revisões bibliográficas nas normas vigentes sobre o assunto, a fim de estabelecer os critérios e parâmetros de análise. Posteriormente, os modelos de lajes lisas analisados foram definidos e modelados com 0 auxílio do software TQS.

Através da análise estrutural pós puncionamento fornecida pela ferramenta computacional, foi possível obter resultados sobre a necessidade ou não da armadura de punção, assim como determinar seu detalhamento caso seja necessária. Dessa forma, foi possível verificar a possível ocorrência do colapso progressivo.

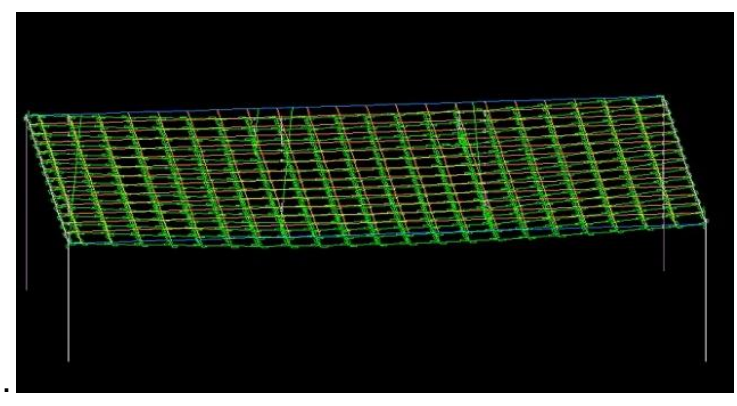

Figura 1. Visualização de laje puncionada no TQS.

\section{Conclusões}

Os resultados obtidos pelo software correspondem aos resultados esperados seguindo os critérios vigentes da norma. $O$ resumo estrutural fornecido pelo TQS apresenta resultados confiáveis e consistentes, visto que ao variar parâmetros gerando situações mais críticas - de forma a concentrar esforços no processo de puncionamento - a necessidade e a capacidade de resistência da armadura de punção demonstrou-se aumentar proporcionalmente em cada situação.

\section{Agradecimentos}

Ao Prof. Dr. Leandro Mouta Trautwein e ao $\mathrm{PIBIC/CNPq}$ por me proporcionarem a oportunidade de realizar este projeto.

\footnotetext{
${ }^{1}$ ABNT NBR 6118/2014 Projeto de estruturas de concreto Procedimento. Rio de Janeiro.

${ }^{2}$ ACI 318M-14 (2014). Building code Requirements for Reinforced Concrete. ACI 318M-2011, American Concrete Institute.
} 